\title{
Evolution of Chernozems in the southern forest-steppe of the Central Russian upland under long-term cultivation examined in the agro-chronosequences
}

\author{
O.S. Khokhlova ${ }^{\text {a, }}{ }^{*}$, Yu. G. Chendev ${ }^{\text {b }}$, T.N. Myakshina ${ }^{\text {a }}$, A.L. Alexandrovskiy ${ }^{\text {, }}$, \\ A.A. Khokhlov ${ }^{\mathrm{d}}$ \\ a Institute of Physicochemical and Biological Problems of Soil Science, Russian Academy of Sciences, ulitsa Institutskaya, 2, Pushchino, 142290, Russia \\ b BelgorodState University, Belgorod, Russia \\ c Institute of Geography, Russian Academy of Sciences, Staromonetny pereulok, 29, Moscow, 119017, Russia \\ ${ }^{\mathrm{d}}$ Institute of Cell Biophysics, Russian Academy of Sciences, ulitsa Institutskaya, 3, Pushchino, 142290, Russia
}

\section{A R T I C L E I N F O}

\section{Article history:}

Available online 14 November 2014

\section{Keywords:}

Arable Chernozems

Agrogenic evolution

Central Russian upland

Soil organic carbon

Carbonates

\begin{abstract}
A B S T R A C T
Chernozems are the major component of soil cover in the forest-steppe of the Central Russian Upland. They underwent the most significant anthropogenic transformation in terms of duration and scale of development in profiles, due to ploughing. Despite the long list of experimental works, the obtained conclusions are often contradictory. From our point of view, the best way to observe the effect of ploughing on Chernozems is the examination of soils with different durations of cultivation based on an agrochronosequence approach which was used in this study.

The most appreciable changes occurred in the arable Chernozems for the first period after the beginning of cultivation. In the soils with 16 and $<100$ years duration of cultivation, the following changes are observed: $5-7$ to $9 \mathrm{~cm}$ decreasing of the humus profile, compacting of the plough-layer and its initial enrichment by clay, 15-30\% decreasing of the soil organic carbon (SOC) content and stocks in the $0-30$ and $0-50 \mathrm{~cm}$ depths, about $40 \mathrm{~cm}$ uplift of carbonate accumulation, and increasing of soil inorganic carbon (SIC) content and stocks in the $0-100$ and $0-200 \mathrm{~cm}$ depths. These changes occurred due to abrupt decreasing of the plant residues in agriculture, influence of machinery treatment resulting in destruction of the plough-layer structure and this layer compaction, and changes of water regime. In the arable soils with 100-150 and 150-200 years of cultivation, the further compaction of soil mass, loss of SOC and uplifting of carbonates are not observed. There is backfilling of the SOC along the cracks in the middle part of a profile, high activity of burrowing animals, and continuing redistribution of clay fraction in the deeper horizons. These processes resulted in stabilization of SOC stocks in the profile of the arable soils on the "new" reduced level and shifting of carbonates back to the initial (before cultivation) or even lower level of location, concentrations, and stocks in a profile. After 220-240 years of cultivation, high instability of the studied indicators of the humus and carbonate status can be emphasized. Relatively rapid changes occur in Chernozem properties after the beginning of ploughing, with subsequent slowing. The activity of burrowing animals introduces an ambiguity in the trends of development of the longploughed Chernozems in the agrochronosequences we studied. This factor was previously underestimated.
\end{abstract}

๑) 2014 Elsevier Ltd and INQUA. All rights reserved.

\section{Introduction}

Chernozems are the major component of soil cover in the foreststeppe of the Central Russian Upland. They experienced the most

\footnotetext{
* Corresponding author.

E-mail addresses: akhokhlov@mail.ru (O.S. Khokhlova), sciences@mail.ru (Yu.G. Chendev)
}

significant anthropogenic transformation in terms of duration and scale of manifestation due to ploughing because at present more than $60 \%$ of their area is ploughed (Uvarov and Solovichenko, 2010), and this rate was maintained at least from the second half of the 19th century in the region (Oganovskiy, 1911). There is an opinion that Chernozems have undergone such considerable changes in the process of ploughing that it is impossible to consider them as true Chernozem-type soils (Gerasomov, 1983). 
The most conceptual and system ideas on the transformation of Chernozems under cultivation are expressed in the works by I.I. Lebedeva. In her point of view the replacement of natural biota by cultural ones is the trigger and the first step in the long series of interconnected changes in humus status, water-physical properties, water and temperature regimes in the arable Chernozems (Lebedeva et al., 2013). At first, the cultural vegetation radically changes the quantity of organic residues annually entered in a soil and their distribution within a profile which reduce the content of humus in arable soils. A direct consequence of vegetation replacement is the change of soil climate, which is most contrasting in the plough-layer. The temperature regime of soils becomes more continental because the amplitude of daily and annual temperatures increases. Then, the humidization of the water regime occurs. This regime still remains periodically percolative but due to a reduction of water consumption in autumn after harvesting the deficit of moisture is reduced, and in spring the precipitation penetrates to a greater depth than in the virgin Chernozems (Kokovina and Lebedeva, 1986; Shcheglov, 1999). Under long-term cultivation the water regime of arable Chernozems varies in two opposite directions (Lebedeva, 2002). In the upper part of the profile, the water regime becomes more arid due to the intense evaporation inside the soil profile, while the lower layers of profile including the parent rock are overwetted due to accumulation of precipitation unexpended by cultural vegetation. In addition, the water regime changes are closely related to the structural state of arable Chernozems. Ploughing of virgin Chernozems is accompanied by a disintegration of their natural granular structure and compaction of soil mass in the plough-layer. In the dry state, large polygonal blocks with $40-50 \mathrm{~cm}$ in diameter separated by cracks are formed. The density of soil mass in blocks reaches $1.35-1.40 \mathrm{~g} /$ $\mathrm{cm}_{3}$ (sometimes, $1.6 \mathrm{~g} / \mathrm{cm}_{3}$ ), almost equal to the density of the parent rock. Using cracks between those blocks, water from precipitation is immediately drained down in the lower horizons, and in addition, humus material of the upper horizons is transferred to the middle part of the soil profile (Lebedeva et al., 2013).

Review of studies devoted to the particular aspects of the agrogenic transformation of Chernozems shows that researchers make contradictory and often mutually exclusive conclusions about the changes of soil properties and the reasons that led to these changes. Within a short article it is impossible to consider the problem in detail; we will focus only on those issues that are relevant to our work. For instance, there are three opinions on the changes of humus profile thickness in arable Chernozems: the thickness decreases (Aderikhin, 1964; Agroecological state of Chernozems in the Central Chernozemic Region of Russia (1996); Ushacheva and Zvyagintsev, 2000; Ivanov and Tabanakova, 2003), does not change (Afanasyeva, 1964; Natural and anthropogenic geosystems of the central forest-steppe of the Russian plain, 1989; Akhtyrtsev, 1991), or increases (Denisov, 1935; Lazarev, 1936; Brook, 1979; Sinkevich, 1989). The decrease of thickness is explained by long-term erosion together with the effect of arable compaction. The rate of anthropogenically-provoked water denudation is estimated at $1.0-1.2 \mathrm{~cm} / 100$ years (Ivanov and Tabanakova, 2003). Invariability of thickness is explained by enhancement of accumulation of humus in the subsurface horizons. An increase of thickness of humus profile is supposed to be a result of an intensification of illuviation of humus in the process of ploughing.

All researchers agree that the ploughing of Chernozems is definitely accompanied by a loss of their organic matter. However, the authors' opinions regarding the intensity of dehumification in arable Chernozems diverge significantly. Together with the view of the rapid, almost catastrophic dehumification of arable Chernozems in the 20th century (Sidorov et al., 1983; Zonn and Travleev,
1989), there are ideas that the loss of humus in arable soils within the steppe and forest-steppe zones is grossly exaggerated (Afanasyeva, 1964; Kokovina and Lebedeva, 1990; Orlov et al., 1996; Akhtyrtsev and Akhtyrtsev, 2002). There is no consensus on the question of the duration of dehumification in arable Chernozems. Some researchers (Afanasyeva, 1966; Ponomareva, 1974; Akhtyrtsev and Akhtyrtsev, 2002) think that the loss of humus was very intense in the first decades after the beginning of the ploughing and in the long-term cultivated soils it is completely stopped. Other researchers believe that the dehumification continues over centuries (Aderikhin, 1964; Gedymin and Pobedintseva, 1964).

There are three points of view on change in depth of carbonate location in the arable Chernozems: their occurrence became lower as a result of agro-anthropogenic leaching (Agroecological state of Chernozems in the Central Chernozemic Region of Russia (1996)); depth does not change, but the seasonal pulsation of calcium carbonate has greater amplitude in a new hydrothermal regime (Shcheglov, 1999; Brekhova and Shcheglov, 2001); or the level of carbonates rose due to increasing physical evaporation from the surface of arable fields at the beginning and end of vegetation period as well as on fallow fields (Afanasyeva, 1964, 1966; Pobedintseva, 1989; Lebedeva, 2002).

The depletion of the plough-layer by clay fraction in the zonal row from the northern sub-types of Chernozems to Kastanozems has been noted by various authors (Brook, 1979; Shcheglov, 1999; Akhtyrtsev and Akhtyrtsev, 2002; Kozlowskiy, 2003 and others). Removal of clay as a result of agro-lessivage occurs in the subsurface part of the soil profile and is implemented in a layer of "sole shoe" (Akhtyrtsev and Akhtyrtsev, 2002; Kozlowskiy, 2003). However, according to other observations in arable steppe Chernozems, the balance of clay fraction in relation to the parent rock is moved in the negative direction for the whole soil profile (Shcheglov, 1999). The joint action of processes of argilization and agro-lessivage in arable Chernozems of steppe and forest-steppe zones are also noted (Agroecological state of Chernozems in the Central Chernozemic Region of Russia (1996); Butova et al., 1996).

Thus, long-term and unbalanced agricultural impact has led to the disturbance of Chernozems under the influence of a whole range of negative processes which reduced their fertility. To develop measures for the rational use and protection of Chernozems and to predict their ecological status in future, a wide range of scientific data is needed including information about the changes of soil properties and processes as a result of their long-term agricultural development. Despite the long list of experimental works, the obtained contradictory conclusions hamper the development of theory of agrogenic evolution of Chernozems. This theory is far from complete, is composed of individual fragments, and only partially reflects the general trends that need to be verified, and does not cover all the diversity of soil changes occurring under cultivation (Ivanov et al., 2013).

From our point of view, the best way to investigate successfully the effect of cultivation on the changes of Chernozems' properties is to study the soils with different durations of agricultural use based on an agrochronosequence approach. This research methodology was already previously used (Gedymin and Kharitonychev, 1964; Gedymin and Pobedintseva, 1964; Akhtyrtsev and Shchetinina, 1969; Kozlowskiy, 2003). However, the soils studied were located far from each other, and similar lithologic and geomorphological conditions for those soils were not guaranteed.

According to the approach suggested (Chendev, 2008) and used by us, the study area before the ploughing was a single landscape with identical vegetation, soil, relief, and parent rocks. Different plots of each site were under ploughing for different times and are adjacent. We use the archival large-scale cartographic materials 
made at different times since the second half of the 18th century to determine the duration of agricultural use for different soils within an agrochronosequence studied. The maximal duration of ploughing for the soils inside a site that was possible to study with such approach is $220-240$ years, as the earliest archival maps were made in 1765-1785.

Some researchers noted that the agricultural use of soils in the forest-steppe area of Russia for 200-500 years leads to irreversible changes, for instance to decreasing of content and stocks of organic matter over the entire profile (Karavaeva et al., 1989; Shcheglov, 1999). Probably, the study of cultivated steppe soils in Europe could help to understand the evolution of the most long-term ploughed soils, as the ploughing began earlier in this region than in Russia. But in the 1980s and 1990s in Central Europe, USA, Canada, and China, there was a change of strategy in agricultural soil treatment, toward using sustainable land management practices. Therefore, recent studies of agricultural evolution of steppe soils outside Russia are commonly devoted to changes in their properties under no-tillage (Al-Kaisi et al., 2005; Blanco-Canqui et al., 2011; Yu et al., 2013; Francaviglia et al., 2014), whereas in Russia the conventional tillage is mainly used. The aim of this work is to study the evolution of Chernozems in the southern foreststeppe of the Central Russian upland under long-term cultivation examined in the agro-chronosequences.

\section{Materials and methods}

\subsection{Study sites}

The study was conducted on five different key sites in the Belgorod oblast (Fig. 1). Each study site included one (agro)-chronosequence that consisted of unploughed Chernozems under meadow grassland steppe (four key sites) or under deciduous forest (one key site) and agricultural soils that were under cultivation for $<100,100-150,150-200$, and $220-240$ years. The quantity of soil pits opened at each site is different and listed in Table 1. In the most cases we studied a pair of pits on similarly-aged lands. The distance between the pits in a pair was $5-10 \mathrm{~m}$. The duration of cultivation

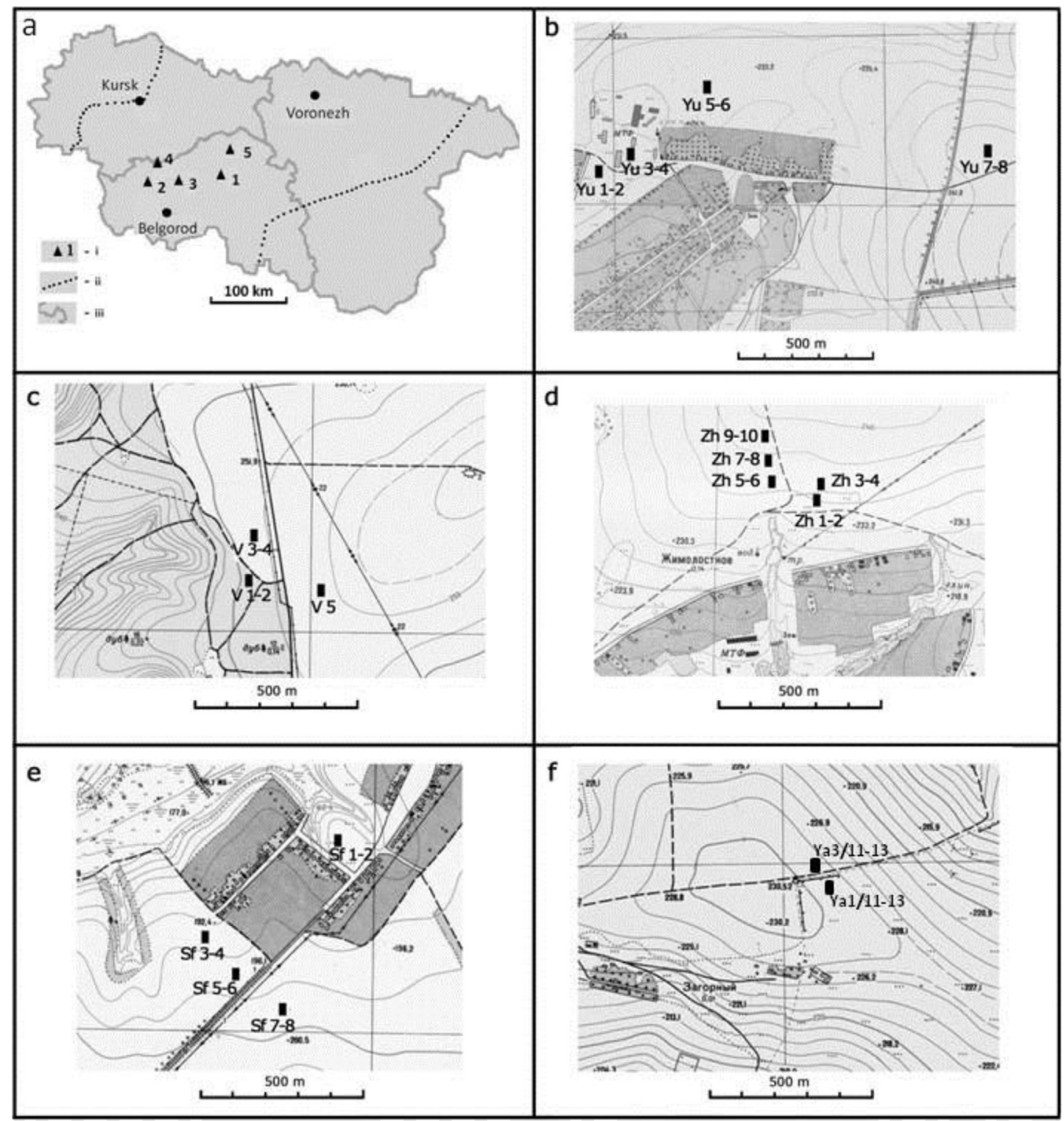

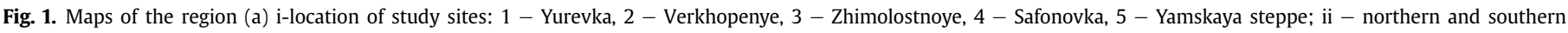
boundaries of the Russian Central forest-steppe; iii - administrative boundaries of the Kursk, Voronezh and Belgorod oblasts; and study sites (b-f). 
was determined for each plot within the study sites based on ancient maps, including Plans of General (the end of the 18th century) and Special large-scale land survey (the middle of the 19th century) of the Russian Empire (1:84,000 scale). In addition, archival, literary information, and interviewing of elderly local residents were also used. With the help of the latter, for instance, on the Yurevka site (Table 1, a) an agricultural field that had been under 16 years cultivation was found within private farmland. Archival material of the natural reserve "Belogorie" helped to understand the duration of ploughing for lands adjoining the Yamskaya steppe site (Table 1, e). On the map of each site, the pairs of pits on plots ploughed for different times are shown (Fig. 1, b-f). Detailed description of the procedure of a soil agrochronosequence choice can be found in Khokhlova et al. (2014).
Soils were classified according to the USSR soil classification system (1977) as Leached and Typical sub-types of Chernozems. According to WRB the Leached sub-type of Chernozems in the Russian forest-steppe are classified as Luvic Chernozems; and the Typical sub-type - as Haplic (Chernic) Chernozems. In the recent Russian classification of soils (Classification ..., 2004), all cultivated soils in the southern part of the Russian forest-steppe area are classified as Agro-Chernozems.

\subsection{History of land use}

The overview of historical, archival, and archaeological data on ancient land use in the Central Russian forest-steppe area show that its southern part (where our study sites situated) was ploughed for

Table 1

Site characteristics of the agricultural chronosequences and the un-ploughed soils in Belgorod region

\begin{tabular}{|c|c|c|c|c|c|c|c|c|c|c|c|c|c|}
\hline \multirow{2}{*}{$\begin{array}{l}\text { Name and location } \\
\text { of the study site }\end{array}$} & \multirow{2}{*}{$\begin{array}{l}\text { Latitude } \\
\text { and longitude }\end{array}$} & \multirow{2}{*}{$\begin{array}{l}\text { MAT, } \\
\left({ }^{\circ} \mathrm{C}\right)\end{array}$} & \multirow{2}{*}{$\begin{array}{l}\text { T July } \\
\left({ }^{\circ} \mathrm{C}\right)\end{array}$} & \multirow{2}{*}{$\begin{array}{l}\text { T January } \\
\left({ }^{\circ} \mathrm{C}\right)\end{array}$} & \multirow{2}{*}{$\begin{array}{l}\text { MAP } \\
(\mathrm{mm})\end{array}$} & \multirow[t]{2}{*}{ HTC } & \multirow{2}{*}{$\begin{array}{l}\text { Height } \\
\text { m.a.s.l. }\end{array}$} & \multicolumn{6}{|c|}{ Number of soil pits } \\
\hline & & & & & & & & $\begin{array}{l}\text { Un- } \\
\text { ploughed }\end{array}$ & $\begin{array}{l}\text { Agricult } \\
16 \mathrm{yr}\end{array}$ & $\begin{array}{l}\text { Agricult } \\
\leq 100 \mathrm{yr}\end{array}$ & $\begin{array}{l}\text { Agricult } \\
100-150 \mathrm{yr}\end{array}$ & $\begin{array}{l}\text { Agricult } \\
150-200 \mathrm{yr}\end{array}$ & $\begin{array}{l}\text { Agricult } \\
220-240 \mathrm{yr}\end{array}$ \\
\hline \multirow{2}{*}{$\begin{array}{l}\text { a. Yurevka, } \\
\text { Gubkinsky district }\end{array}$} & $37^{\circ} 21^{\prime} 29.93^{\prime \prime} \mathrm{E}$ & +7.6 & +21.1 & -7.6 & 550 & 1.12 & 210 & Yu 1/11 & Yu 3/11 & & & Yu 5/11 & Yu 7/11 \\
\hline & $51^{\circ} 3^{\prime} 13.59^{\prime \prime} \mathrm{N}$ & & & & & & -220 & Yu 2/11 & $\mathrm{Yu} 4 / 11$ & & & Yu 6/11 & Yu 8/11 \\
\hline \multirow{2}{*}{$\begin{array}{l}\text { b. Verkhopenye, } \\
\text { Ivnyansky district }\end{array}$} & $36^{\circ} 17^{\prime} 18.83^{\prime \prime} \mathrm{E}$ & +7.6 & +20.9 & -6.7 & 550 & 1.19 & 250 & V $1 / 10$ & & & V 3/10 & & V 5/10 \\
\hline & $50^{\circ} 56^{\prime} 56.58^{\prime \prime} \mathrm{N}$ & & & & & & -253 & V $2 / 10$ & & & $\mathrm{~V} 4 / 10$ & & \\
\hline \multirow{2}{*}{$\begin{array}{l}\text { c. Zhimolostnoye, } \\
\text { Prokhorovsky } \\
\text { district }\end{array}$} & $36^{\circ} 43^{\prime} 42.35^{\prime \prime} \mathrm{E}$ & +7.7 & +20.6 & -6.8 & 550 & 1.12 & 255 & Zh $1 / 11$ & & Zh 3/11 & Zh 5/11 & Zh $7 / 11$ & Zh 9/11 \\
\hline & $50^{\circ} 57^{\prime} 3.38^{\prime \prime} \mathrm{N}$ & & & & & & -260 & Zh $2 / 11$ & & Zh $4 / 11$ & Zh $6 / 11$ & Zh $8 / 11$ & Zh 10/11 \\
\hline \multirow{4}{*}{$\begin{array}{l}\text { d. Safonovka } \\
\text { Ivnyansky district } \\
\text { e. Yamskaya steppe, } \\
\text { Gubkinsky district }\end{array}$} & $36^{\circ} 23^{\prime} 44.44^{\prime \prime} \mathrm{E}$ & +7.6 & +20.9 & -6.7 & 550 & 1.18 & 220 & Sf $1 / 13$ & & & Sf $3 / 13$ & Sf $5 / 13$ & Sf $7 / 13$ \\
\hline & $51^{\circ} 5^{\prime} 53.86^{\prime \prime} \mathrm{N}$ & & & & -555 & & -225 & Sf $2 / 13$ & & & Sf $4 / 13$ & Sf $6 / 13$ & Sf $8 / 13$ \\
\hline & $37^{\circ} 20^{\prime} 59.62^{\prime \prime} \mathrm{E}$ & +7.9 & +21.3 & -7.3 & 530 & 1.2 & 215 & Ya 1/11 & & Ya 3/11 & & & \\
\hline & $50^{\circ} 57^{\prime} 48.77^{\prime \prime} \mathrm{N}$ & & & & & & -225 & Ya $1 / 13$ & & Ya 3/13 & & & \\
\hline
\end{tabular}

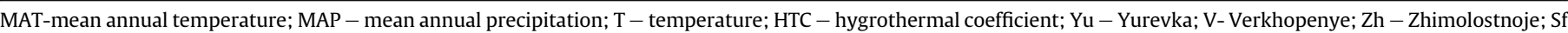

- Safonovka; Ya- Yamskaya steppe; Agricult - agriculture; yr - years.

An important condition for choice of a soil agrochronosequence was the topography, parent material, and adjacency of arable soils that have been under different durations of cultivation near a fragment of un-ploughed (virgin) parcel of land. The preference was for loam soils located on flat or weakly inclined watersheds, to minimize the action of erosion due to water or tillage. The majority of un-ploughed, non-cultivated soils in the studied key-sites are located on hayfields or pastures. In the case of the Verhopenye site (Table 1, b) it is deciduous light forest. The Yamskaya steppe site (Table 1, e) is virgin steppe with annual mowing of grass within the natural reserve "Belogorie". The list of all the pits studied within each site is in Table 2.
320-120 years, and the lands with the longest ploughing period did not contain un-ploughed plots (Chendev, 2008). Our study sites are situated within or close to the flat watersheds, in which agriculture started only since the widespread of cultivation (from the second half of the 18th century). Before this time from very ancient historical periods (Neolithic-Paleolithic) these lands developed under natural factors of soil formation only.

Depth of tillage in the 18th-beginning of the 19th centuries was relatively shallow $(\sim 15 \mathrm{~cm})$. Directional trend of increasing tillage depth (up to $30 \mathrm{~cm}$ or more) was observed from the 1930s until the end of the 1980s. At 2000-2010 at several sites, the opposite trend of decreasing tillage depth was observed in connection with

Table 2

Morphological characteristics of the studied profiles

\begin{tabular}{|c|c|c|c|c|c|}
\hline $\begin{array}{l}\text { Duration of } \\
\text { ploughing }\end{array}$ & Pit & Horizon & Depth, cm & $\begin{array}{l}\text { Depth of reaction } \\
\text { with } 10 \% \mathrm{HCl}, \mathrm{cm}\end{array}$ & Name of soil \\
\hline \multicolumn{6}{|c|}{ The Yurevka site is located in a typical steppe landscape on the watershed between the Korocha and Oskol Rivers on flat surface. } \\
\hline 0 & Yu 1/11 & $\begin{array}{l}\text { Ah1 } \\
\text { Ah2 } \\
\text { AhB } \\
\text { Bk } \\
\text { BCk } \\
\text { Ck }\end{array}$ & $\begin{array}{l}0-6 \\
6-62 \\
62-82 \\
82-107 \\
107-125 \\
125-200\end{array}$ & 114 & $\begin{array}{l}\text { Typical Chernozem transitioned to the Leached one, thick, heavy loam } \\
\text { on calcareous loess-like loam }\end{array}$ \\
\hline 0 & Yu 2/11 & $\begin{array}{l}\text { Ah1 } \\
\text { Ah2 } \\
\text { AhB } \\
\text { Bk } \\
\text { BCk } \\
\text { Ck }\end{array}$ & $\begin{array}{l}0-8 \\
8-61 \\
61-91 \\
91-118 \\
118-140 \\
140-200\end{array}$ & 37 & Typical Chernozem, thick, heavy loam on calcareous loess-like loam \\
\hline 16 & Yu 3/11 & $\begin{array}{l}\text { Ap } \\
\text { Ah } \\
\text { AhB }\end{array}$ & $\begin{array}{l}0-20 \\
20-41 \\
41-64\end{array}$ & 72 & $\begin{array}{l}\text { Arable Typical Chernozem, thick, heavy loam on calcareous loess-like } \\
\text { loam }\end{array}$ \\
\hline
\end{tabular}


Table 2 (continued)

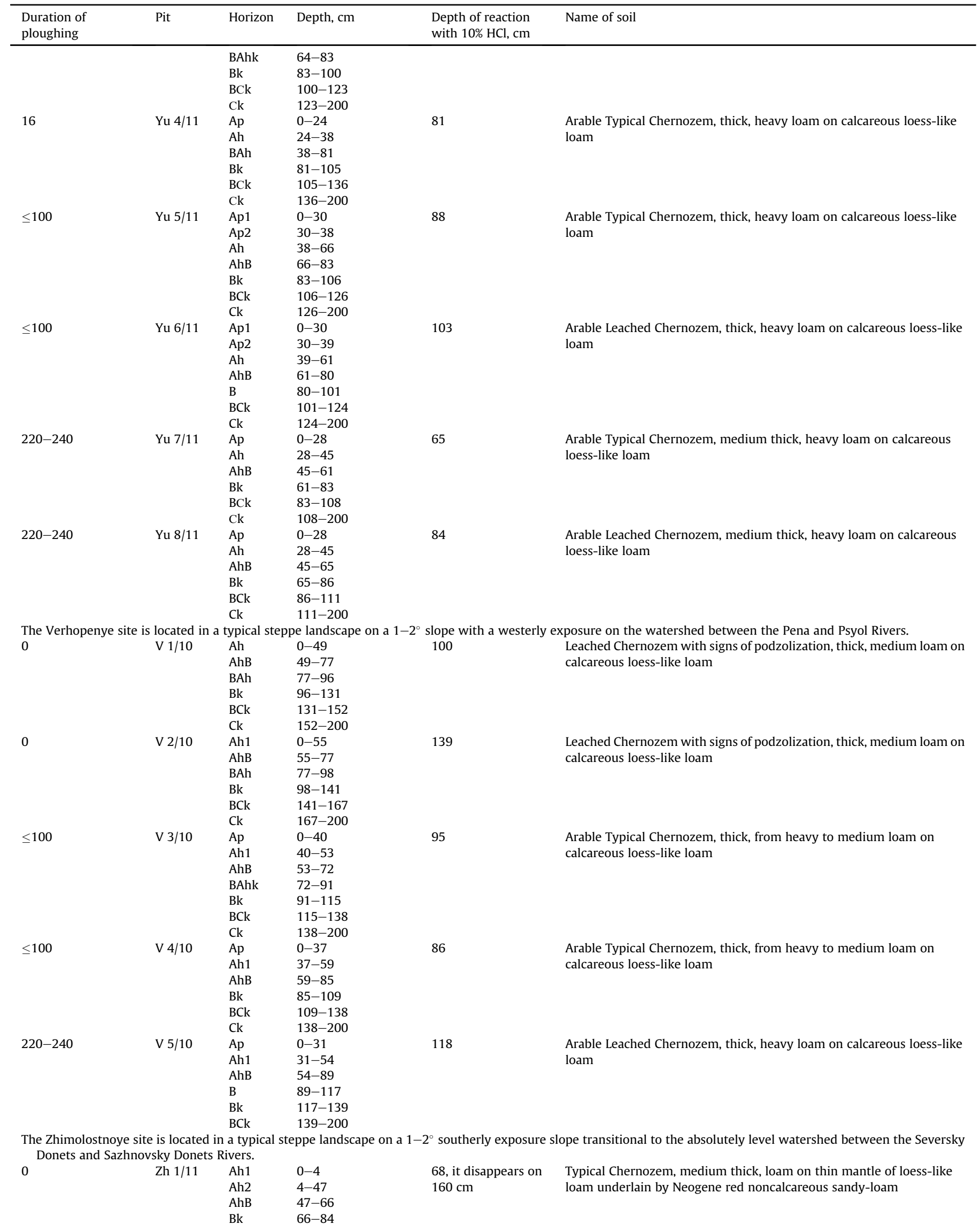


Table 2 (continued)

\begin{tabular}{|c|c|c|c|c|c|}
\hline $\begin{array}{l}\text { Duration of } \\
\text { ploughing }\end{array}$ & Pit & Horizon & Depth, cm & $\begin{array}{l}\text { Depth of reaction } \\
\text { with } 10 \% \mathrm{HCl}, \mathrm{cm}\end{array}$ & Name of soil \\
\hline & & $\mathrm{BCk}$ & $84-104$ & & \\
\hline & & D1k & $104-131$ & & \\
\hline & & D2 & $131-200$ & & \\
\hline \multirow[t]{7}{*}{0} & Zh $2 / 11$ & Ah1 & $0-5$ & 96, it disappears on & Leached Chernozem, medium thick, loam on thin mantle of loess-like \\
\hline & & Ah2 & $5-52$ & $150-160 \mathrm{~cm}$ & loam underlain by Neogene red noncalcareous sandy-loam \\
\hline & & AhB & $52-76$ & & \\
\hline & & Bw & $76-95$ & & \\
\hline & & $\mathrm{BCk}$ & $95-111$ & & \\
\hline & & D1k & $111-156$ & & \\
\hline & & D2 & $156-200$ & & \\
\hline \multirow[t]{7}{*}{$\leq 100$} & Zh 3/11 & Ap & $0-30$ & 67 , it disappears on & Arable Typical Chernozem, medium thick, loam on thin mantle of loess- \\
\hline & & Ah & $30-49$ & $165 \mathrm{~cm}$ & like loam underlain by Neogene red noncalcareous sandy-loam \\
\hline & & AhB & $49-68$ & & \\
\hline & & Bk1 & $68-99$ & & \\
\hline & & $\mathrm{Bk} 2$ & $99-136$ & & \\
\hline & & $\mathrm{BCk}$ & $136-171$ & & \\
\hline & & $\mathrm{D}$ & $171-200$ & & \\
\hline \multirow[t]{7}{*}{$\leq 100$} & Zh $4 / 11$ & Ap & $0-29$ & 74 , it disappears on & Arable Typical Chernozem, medium thick, loam on thin mantle of loess- \\
\hline & & Ah & $29-46$ & $165 \mathrm{~cm}$ & like loam underlain by Neogene red noncalcareous sandy-loam \\
\hline & & AhB & $46-64$ & & \\
\hline & & Bk1 & $64-95$ & & \\
\hline & & $\mathrm{Bk} 2$ & $95-129$ & & \\
\hline & & $\mathrm{BCk}$ & $129-158$ & & \\
\hline & & $\mathrm{D}$ & $158-200$ & & \\
\hline \multirow[t]{7}{*}{$100-150$} & Zh 5/11 & Ap & $0-24$ & $>200$ & Arable (strongly-)Leached Chernozem, gleyed loam on thin mantle of \\
\hline & & $\mathrm{Ah}$ & $24-56$ & & loess-like loam on noncalcareous heavy loess-like loam \\
\hline & & AhB & $56-80$ & & \\
\hline & & Bt1 & $80-110$ & & \\
\hline & & Bt2 & $110-134$ & & \\
\hline & & $\mathrm{BtCg}$ & $134-152$ & & \\
\hline & & $\mathrm{BCg}$ & $152-200$ & & \\
\hline \multirow[t]{8}{*}{$100-150$} & Zh 6/11 & Ap & $0-25$ & 45 , it disappears on & Arable Typical Chernozem, thick, loam on thin mantle of loess-like loam \\
\hline & & $\mathrm{Ah}$ & $25-42$ & $175 \mathrm{~cm}$ & underlain by Neogene red noncalcareous loam \\
\hline & & AhB & $42-65$ & & \\
\hline & & BAhk & $65-99$ & & \\
\hline & & Bk1 & $99-126$ & & \\
\hline & & $\mathrm{Bk} 2$ & $126-152$ & & \\
\hline & & $\mathrm{BCk}$ & $152-173$ & & \\
\hline & & $\mathrm{Cg}$ & $173-200$ & & \\
\hline \multirow[t]{7}{*}{$150-200$} & Zh $7 / 11$ & Ap & $0-26$ & $>200$ & Arable (strongly-)Leached Chernozem, thick, gleyed loam on \\
\hline & & Ah & $26-52$ & & noncalcareous heavy loess-like loam \\
\hline & & AhB & $52-68$ & & \\
\hline & & BAh & $68-82$ & & \\
\hline & & Bt1 & $82-150$ & & \\
\hline & & Bt2 & $150-172$ & & \\
\hline & & $\mathrm{BtC}$ & $172-200$ & & \\
\hline \multirow[t]{8}{*}{$150-200$} & Zh $8 / 11$ & Ap & $0-24$ & 105 & Arable Typical Chernozem, thick, medium loam on calcareous loess-like \\
\hline & & $\mathrm{Ah}$ & $24-38$ & & heavy loam underlain by Neogene red noncalcareous loam \\
\hline & & AhB & $38-63$ & & \\
\hline & & BAh & $63-88$ & & \\
\hline & & B & $88-110$ & & \\
\hline & & $\mathrm{Bk}$ & $110-132$ & & \\
\hline & & $\mathrm{BCk}$ & $132-165$ & & \\
\hline & & $\mathrm{Ck}$ & $165-200$ & & \\
\hline \multirow[t]{8}{*}{$220-240$} & Zh 9/11 & Ap & $0-25$ & 98 & Arable Typical Chernozem transitioned to the Leached one, medium \\
\hline & & Ah1 & $25-36$ & & thick, loam on calcareous loess-like heavy loam underlain by Neogene \\
\hline & & AhB & $36-55$ & & red noncalcareous loam \\
\hline & & BAh & $55-69$ & & \\
\hline & & B1 & $69-97$ & & \\
\hline & & Bgk & $97-138$ & & \\
\hline & & $\mathrm{BCg}$ & $138-170$ & & \\
\hline & & $\mathrm{Dg}$ & $170-200$ & & \\
\hline \multirow[t]{7}{*}{$220-240$} & Zh 10/11 & Ap & $0-24$ & 65 & Arable Typical Chernozem, medium thick, loam on calcareous loess-like \\
\hline & & AhB & $24-53$ & & heavy loam underlain by Neogene red noncalcareous loam \\
\hline & & BAh & $53-76$ & & \\
\hline & & Bk1 & $76-109$ & & \\
\hline & & $\mathrm{Bk} 2$ & $109-149$ & & \\
\hline & & $\mathrm{BCk}$ & $149-168$ & & \\
\hline & & $\mathrm{D}$ & $168-200$ & & \\
\hline $\begin{array}{l}\text { The Safonovl } \\
\text { Solotinka }\end{array}$ & ocated in a & pical step & landscape o & ortherly exposure slop & transitional to the absolutely level watershed between the Psel and \\
\hline 0 & Sf $1 / 13$ & Ah1 & $0-4$ & 29 & Typical carbonated Chernozem, thick, loam on calcareous loess-like \\
\hline & & Ah2 & $4-27$ & & loam \\
\hline & & Ahk & $27-63$ & & \\
\hline
\end{tabular}


Table 2 (continued)

\begin{tabular}{|c|c|c|c|c|c|}
\hline $\begin{array}{l}\text { Duration of } \\
\text { ploughing }\end{array}$ & Pit & Horizon & Depth, cm & $\begin{array}{l}\text { Depth of reaction } \\
\text { with } 10 \% \mathrm{HCl}, \mathrm{cm}\end{array}$ & Name of soil \\
\hline & & AhBk & $63-94$ & & \\
\hline & & $\mathrm{Bk}$ & $94-131$ & & \\
\hline & & $\mathrm{BCk}$ & $131-200$ & & \\
\hline \multirow[t]{5}{*}{0} & Sf $2 / 13$ & Ah1 & $0-5$ & 81 & Leached Chernozem, thick, loam on calcareous loess-like loam \\
\hline & & Ah2 & $5-62$ & & \\
\hline & & AhB & $62-85$ & & \\
\hline & & $\mathrm{Bk}$ & $85-117$ & & \\
\hline & & $\mathrm{BCk}$ & $117-200$ & & \\
\hline \multirow[t]{5}{*}{$100-150$} & Sf $3 / 13$ & Ap & $0-30$ & 54 & Arable Typical Chernozem, thick, loam on calcareous loess-like loam \\
\hline & & Ah & $30-56$ & & \\
\hline & & AhBk & $56-95$ & & \\
\hline & & $\mathrm{Bk}$ & $95-137$ & & \\
\hline & & $\mathrm{BCk}$ & $137-200$ & & \\
\hline \multirow[t]{5}{*}{$100-150$} & Sf $4 / 13$ & Ap & $0-29$ & 31 & Arable Typical Chernozem, thick, loam on calcareous loess-like loam \\
\hline & & Ahk & $29-59$ & & \\
\hline & & AhBk & $59-95$ & & \\
\hline & & $\mathrm{Bk}$ & $95-136$ & & \\
\hline & & $\mathrm{BCk}$ & $136-200$ & & \\
\hline \multirow[t]{5}{*}{$150-200$} & Sf $5 / 13$ & Ap & $0-26$ & 73 & Arable Typical Chernozem, medium thick, loam on calcareous loess-like \\
\hline & & $\mathrm{Ah}$ & $26-48$ & & loam \\
\hline & & AhB & $48-78$ & & \\
\hline & & $\mathrm{Bk}$ & $78-123$ & & \\
\hline & & $\mathrm{BCk}$ & $123-200$ & & \\
\hline \multirow[t]{5}{*}{$150-200$} & Sf $6 / 13$ & Ap & $0-28$ & 132 & Arable Leached Chernozem, thick, loam on calcareous loess-like loam \\
\hline & & $\mathrm{Ah}$ & $28-56$ & & \\
\hline & & AhB & $56-88$ & & \\
\hline & & $\mathrm{Bk}$ & $88-128$ & & \\
\hline & & $\mathrm{BCk}$ & $128-200$ & & \\
\hline \multirow[t]{5}{*}{$220-240$} & Sf $7 / 13$ & Ap & $0-28$ & 46 & Arable Typical Chernozem, thick, loam on calcareous loess-like loam \\
\hline & & $\mathrm{Ah}$ & $28-39$ & & \\
\hline & & AhBk & $39-85$ & & \\
\hline & & $\mathrm{Bk}$ & $85-149$ & & \\
\hline & & $\mathrm{BCk}$ & $149-200$ & & \\
\hline \multirow[t]{6}{*}{$220-240$} & Sf $8 / 13$ & Ap & $0-27$ & 134 & Arable Leached Chernozem, thick, loam on calcareous loess-like loam \\
\hline & & $\mathrm{Ah}$ & $27-49$ & & \\
\hline & & AhB & $49-67$ & & \\
\hline & & BAh & $67-88$ & & \\
\hline & & B & $88-122$ & & \\
\hline & & $\mathrm{BCk}$ & $122-200$ & & \\
\hline \multicolumn{6}{|c|}{$\begin{array}{l}\text { The Yamskaya steppe site is located in the natural reserve "Belogorie" on the area representing the southern variant of meadow steppes with thick Chernozems. Studied } \\
\text { pits are located on a } 3-5^{\circ} \text { north-easterly exposure slope on watershed between the Oskol and Oskoletz Rivers. }\end{array}$} \\
\hline \multirow[t]{8}{*}{0} & Ya $1 / 11$ & Ah1 & $0-15$ & 98 & Typical Chernozem, thick, heavy loam on calcareous loess-like loam \\
\hline & & Ah2 & $15-42$ & & \\
\hline & & Ah3 & $42-62$ & & \\
\hline & & AhB & $62-83$ & & \\
\hline & & BAh & $83-98(105)$ & & \\
\hline & & Bk1 & $98(105)-140(145)$ & & \\
\hline & & $\mathrm{BCk}$ & $140(145)-180$ & & \\
\hline & & $\mathrm{Ck}$ & $180-200$ & & \\
\hline \multirow[t]{7}{*}{0} & Ya $1 / 13$ & Ah1 & $0-18(24)$ & $62(72)$ & Typical Chernozem transitioned to Leached one, thick, middle loam on \\
\hline & & Ah2 & $18(24)-38(40)$ & & calcareous loess-like loam underlain by Neogene red loam \\
\hline & & Ah3 & $38(40)-62(72)$ & & \\
\hline & & AhB & $62(72)-90(100)$ & & \\
\hline & & Bk1 & $90(100)-115(130)$ & & \\
\hline & & $\mathrm{BCk}$ & $115(130)-155$ & & \\
\hline & & Ck-Dk & $155-200$ & & \\
\hline$\leq 100$ & Ya 3/11 & Ap & $0-27$ & 33 & Arable Typical Chernozem, thick, heavy loam on calcareous loess-like \\
\hline & & Ah1 & $27-50$ & & loam \\
\hline & & Ah2 & $50-65$ & & \\
\hline & & AhB & $65-85(90)$ & & \\
\hline & & BAh & $85(90)-107(113)$ & & \\
\hline & & Bk1 & $107(113)-145(150)$ & & \\
\hline & & $\mathrm{BCk}$ & $145(150)-180$ & & \\
\hline & & $\mathrm{Ck}$ & $180-200$ & & \\
\hline$\leq 100$ & Ya $3 / 13$ & Ap1 & $0-8$ & $78(80)$ & Arable Typical Chernozem, middle thick, middle loam on calcareous \\
\hline & & Ap2 & $8-29$ & & loess-like loam underlain by Neogene red loam \\
\hline & & $\mathrm{Ah}$ & $29-45(48)$ & & \\
\hline & & AhB & $45(48)-58(60)$ & & \\
\hline & & BAh & $58(60)-78(80)$ & & \\
\hline & & Bk1 & $78(80)-110(117)$ & & \\
\hline & & $\mathrm{Bk} 2$ & $110(117)-147(150)$ & & \\
\hline & & $\mathrm{BCk}$ & $147(150)-192$ & & \\
\hline & & $\mathrm{Dk}$ & $192-200$ & & \\
\hline
\end{tabular}


applying of new technologies (using land clearer and disking). Notillage for the arable soils in the Belgorod oblast is not widespread. Thus, all arable areas in the studied sites are characterized by a similar history of land use: from treatment by horse-drawn plough (before the 1930s) to machining using tractors, but the periods of influence of different land treatments were different. The soils which were ploughed more than 100 years ago were under the relatively "soft" influence (horse traction, narrow bands of ploughed lands with many boundary paths) during the first 100-150 years, whereas the soils with $<100$ years length of ploughing were the subject of "modem type" impact (deep ploughing by heavy machines) from the very beginning of ploughing (Aleksandrovskiy, 1988).

In addition, until the middle of the 1950s the arable Chernozems did not receive fertilizers, or doses of fertilizers were small and were used fragmentarily. Since the 1960s, fertilizers were applied systematically, but their doses continued to be below the recommended standards. Annual doses of solid manure never exceeded 5-6 t/ha, whereas the sufficient doses to maintain the deficit-free humus balance in the Chernozems should be not less than $10 \mathrm{t} / \mathrm{ha}$.

\subsection{Soil description, sampling, and analysis}

At each site, soil pits were dug to $200 \mathrm{~cm}$ depth. All soil pits of the sites were described and photographed. Measurement of thickness for soil horizons $(n=15-30)$ was made along the walls of all soil pits, and the average values were calculated.

Samples were extracted from all the pits in 2010-2013. From the upper $100 \mathrm{~cm}$ of the profile, samples $(n=3)$ were collected at $10 \mathrm{~cm}$ intervals, and at $20 \mathrm{~cm}$ intervals from 100 to $200 \mathrm{~cm}$ depth. Soil bulk density was determined in the field using a hand-operated auger $(n=3)$ to $70 \mathrm{~cm}$ depth and by ring auger to $200 \mathrm{~cm}$. In some places, drilling was used to determine the soil moisture: samples was collected in hermetical weighing bottles and weighed before and after drying at $105^{\circ} \mathrm{C}$, and then the percentage of soil moisture was calculated. We compared moisture content in those sites where the samples for its determination were collected in April, 2010-2013 (Verkhopenye, Zhimolostnoye and Safonovka sites, Table 1).

In the laboratory, the SOC for all samples was determined using the Turin method of wet combustion (Arinushkina, 1970). The carbonate $\mathrm{CO}_{2}$ was determined by chromatography in sealed vessels with rubber stoppers in which the samples reacted with $10 \%$ $\mathrm{HCl}$ solution and were then converted to $\mathrm{C}$ (SIC). Based on profile distribution of SOC, SIC and the bulk density values for each sampling layer, C stocks within 0-50, 50-100, 100-150, 150-200, $0-100$ and $0-200 \mathrm{~cm}$ were quantified for all sites. The particle-size distribution was determined by pipette method with sodium pyrophosphate for dispersion.

\section{Results}

\subsection{Morphology of profiles, thickness of humus horizon and depth of effervescence with $\mathrm{HCl}$}

The un-ploughed Chernozems studied consist of combinations of the dark-humus (Ah) and carbonate-accumulative (Bk, BCk) horizons formed in calcareous loess, in some cases underlain and mixed with Neogene red noncalcareous loam (Table 2). Biogenic mixing is intense and contributes to granular structure stability, increasing humus profile depth.

Under ploughing, the difference in morphology of similarlyaged arable soils is increased. Especially, the degree of bioturbation by burrowing animals differed in pairs of pits with the same length of cultivation. In the arable soils with $>100$ years duration of cultivation this difference reached maximum. These differences are shown in the photos of pairs of pits in the Safonovka site as the most expressive (Fig. 2).

The carbonates may be absent in one pit of a similarly-aged pair (see pits 5-6 and 7-8 in the Zhimolostnoye, for instance, Table 2). Sometimes, in the arable soils with $>100$ years length of ploughing, the signs of gley process are morphologically visible in the lower part of profiles (appearance of the $\mathrm{Bg}, \mathrm{BCg}, \mathrm{Cg}$ horizons, Table 2).

The comparative analysis of humus profile thickness in the unploughed and arable Chernozems shows its definite reduction in the arable Chernozems with the least duration of ploughing. In the 16 and $<100$ years arable soils (Fig. 3 I a, c, e), the thickness of the $\mathrm{Ap}+\mathrm{Ah}+\mathrm{AhB}$ horizons (i.e., humus profile) is 5-9 $\mathrm{cm}$ less than in the un-ploughed soils. In the100-150 and 150-200 years arable soils, there is no directional trend of change of humus profile thickness, with small increases and decreases (Fig. 3 I b, c, d) or no change (Fig. 3 I a). In the 220-240 years arable soils, in two cases decreases of humus profile thickness is noted (Fig. $3 \mathrm{I}$ a, d), remaining constant in the other two cases (Fig. $3 \mathrm{I}$ b and c), compared with the soils of other lengths of cultivation in an agrochronosequence.

In general, the thickness of the humus profile in all the arable soils is less than in the un-ploughed ones, but only very rarely is this statistically significant. The most plausible explanation is that this difference is ensured during the initial stage of cultivation ( $<100$ years of cultivation), and further changes in thickness of humus profile are connected with spatial variability. The observed trend of the reduction of humus profile thickness in arable soils is the least in the Zhimolostnoye site (Table 1 and Fig. 3 I c) where soils develop on the loess-like loam with significant admixture of Neogene red loams.

The line of effervescence with $\mathrm{HCl}$ is very variable in the soils of the studied agrochronosequences (Fig 2 II). In some cases, the standard deviation is half of the average value of the depth of carbonate. This line is a very easy changeable soil property. Therefore, only approximate can be recognized in the sites studied. In the arable soils under $<100$ and $100-150$ years of cultivation, the line of effervescence with $\mathrm{HCl}$ upwarded to the surface whereas in the soils under 150-200 and 220-240 years of cultivation, this line was located at the initial level or below compared with the unploughed soils. Sometimes this line seems to be practically unchangeable due to very high spatial variability (Fig. 3 II a). In addition, the carbonate accumulation in a profile was connected with burrowing animals' activity, and the positional uncertainty for the line of effervescence with $\mathrm{HCl}$ increased due to very different degrees of digging in the pairs of soils.

\subsection{Soil bulk density}

The 25-35 cm topsoil of all arable soils in the sites studied is more compact than the un-ploughed ones (Fig. 4). In the sites where un-ploughed soils are located in forest (Fig. 4b) and virgin steppe (Fig. 4e), the trend is the clearest, and the bulk density is less than that in the arable soils to $23-35(40) \mathrm{cm}$ depth. There is no difference in the bulk density values between the arable soils with different duration of cultivation in all the sites.

The bulk density of the un-ploughed soils is in the range $0.8-1.1 \mathrm{~g} / \mathrm{cm}_{3}$, whereas in the arable ones it is $1.0-1.3 \mathrm{~g} / \mathrm{cm}_{3}$ in the upper $25-35 \mathrm{~cm}$. These changes in the arable soils are equivalent to about $5-7 \mathrm{~cm}$ compression in the uppermost $40 \mathrm{~cm}$ of the unploughed Chernozems. These values are close to those obtained for decrease of the humus profile thickness, 5-9 cm in the arable soils. Under the virgin steppe vegetation, the un-ploughed soils have the lowest values of bulk density in the uppermost layer, $0.5-0.7 \mathrm{~g} / \mathrm{cm}_{3}$. Grass roots play the leading role in a soil loosening. 

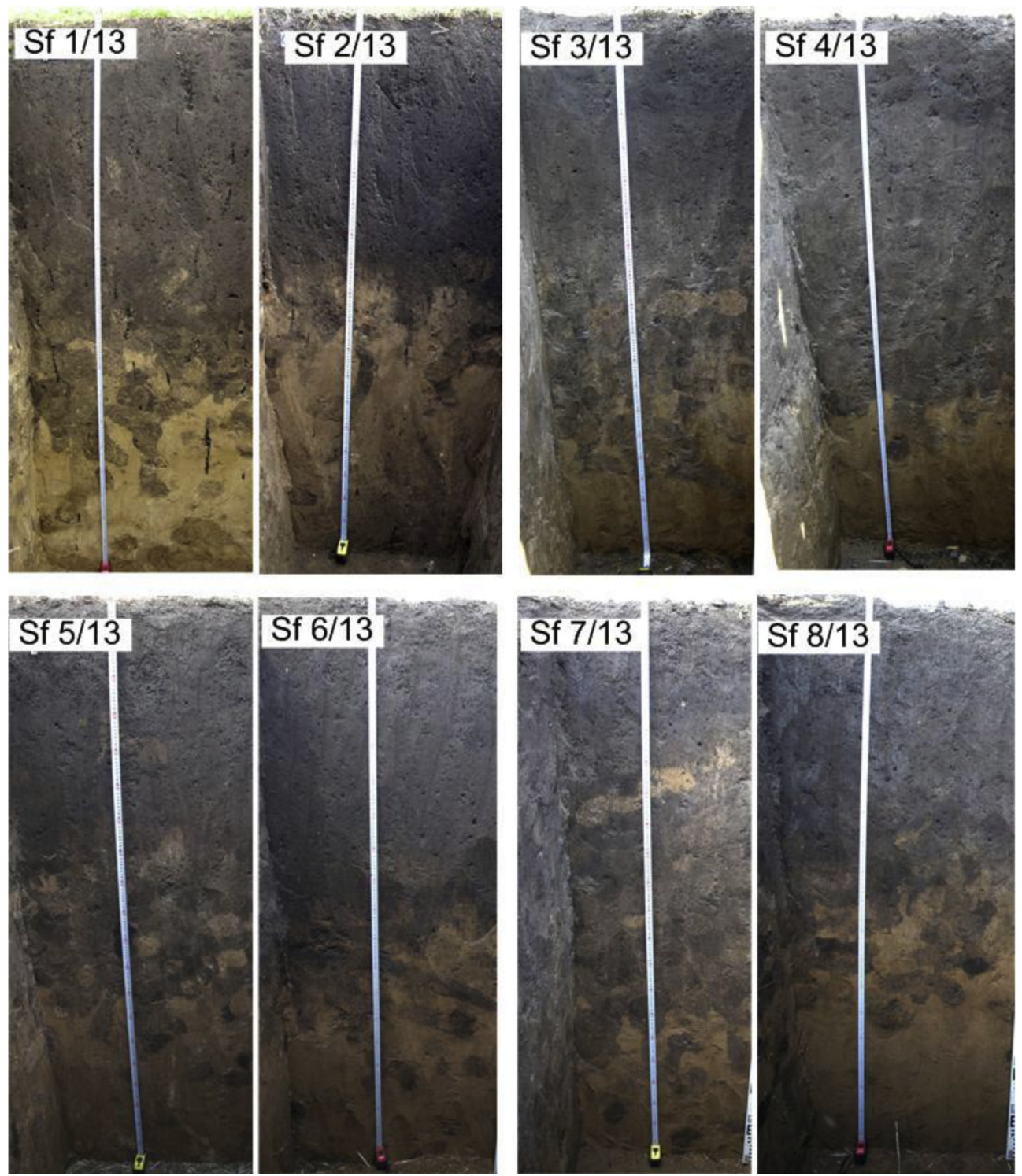

Fig. 2. Photos of the pairs of soil pits for the Safonovka site. Sf-1/13 and Sf 2/13 - un-ploughed soils, Sf 3/13 and Sf 4/13 - soils ploughed for 100-150 years; Sf 5/13 and Sf 6/13 soils ploughed for $150-200$ years; Sf $7 / 13$ and Sf $8 / 13$ - soils ploughed for $220-240$ years.

Deeper than $70 \mathrm{~cm}$, the bulk density values in all studied soils are in the range $1.3-1.5(1.6) \mathrm{g} / \mathrm{cm}_{3}$ without any differences between the un-ploughed and cultivated soils. It is evident that the compaction and the decreasing of the humus profile thickness occurred at the initial terms of cultivation ( $<100$ years), as there are no differences in those properties between arable soils of different lengths of cultivation.

\subsection{Soil field moisture}

We did not conduct measurements of soil field moisture regularly, and the one-time observations in some sites in April of different years (Fig. 4) is only presented to show that the water regime differs for the studied un-ploughed and arable soils. Rainfall and amount of meltwater were very different in 2010, 2011 and 2013, but despite this in all sites the field moisture content was significantly higher (Fig. 5 b, c) or higher (Fig. 5d) in the uppermost $20(40) \mathrm{cm}$ of the un-ploughed soils than the cultivated ones. Below, at $40-65 \mathrm{~cm}$, the moisture contents were practically equal in all studied soils.

\subsection{Content of clay fraction (\%)}

In the arable Chernozems, clay fraction enrichment of the upper part of profiles is observed. This enrichment becomes visible in the soils cultivated for $<100$ years (Fig. 6 c, e) in the $0-20$ and 20-40 cm layers (i.e., in the plough-layer). In the arable Chernozems cultivated for $100-150,150-200$ and $>200$ years this enrichment is traced to $80-100 \mathrm{~cm}$ depth (Fig. 6, a-d). The least clay fraction enrichment of the arable soils is observed in the Zhimolostnoye site (Fig. 6c) due to the highest degree of weathering of the Neogene parent rock.

\subsection{Soil organic carbon concentrations (\%)}

The SOC concentration in the $0-20$ and $20-40 \mathrm{~cm}$ layers of the un-ploughed soils was the highest, $4.2-3.6 \%$ for all our sites (Fig. 7 I). In agricultural soils, the SOC concentration in these layers was 3.0-2.8\% (Fig. 7 I a, b, e) and 2.3-2.6\% (Fig. 7 I c, d). SOC concentration in the central section of the soil profile varied in the agricultural soils depending on the length of cultivation. In the soils 


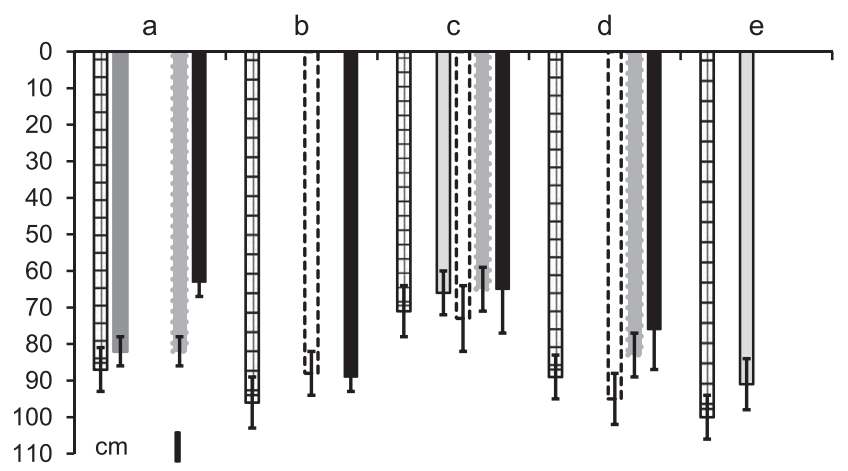

口Un-plowed soils $\quad$ Agricult $16 \mathrm{yr} \quad \square$ Agricult $\leq 100 \mathrm{yr}$

$\therefore$ Agricult 100-150 yr Agricult 150-200 yr Dagricult 220-240 yr

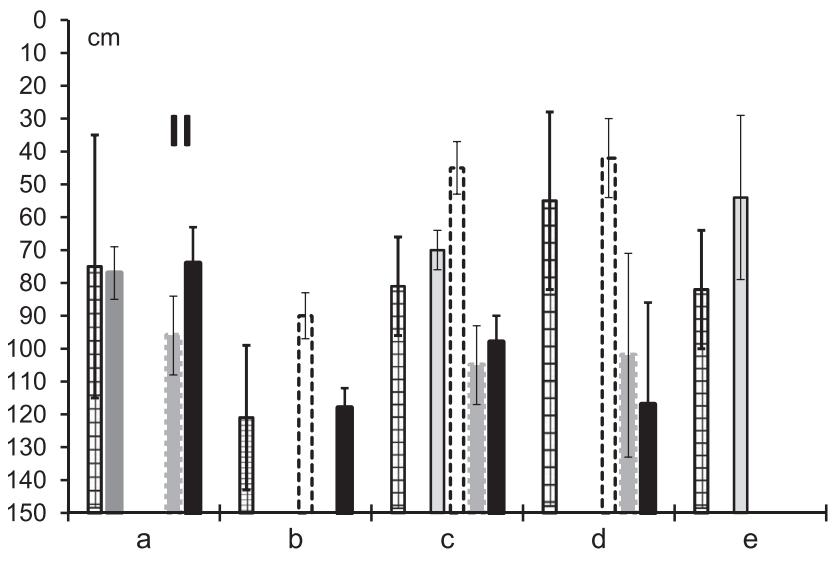

Fig. 3. Average thickness of (I) humus profiles (Ap $+A 1+A B$ horizons) and (II) depth of line of effervescence with $\mathrm{HCl}$ in soils of the key sites: $\mathrm{a}-$ Yurevka, $\mathrm{b}$ - Verkhopenye, $\mathrm{C}$ - Zhimolostnoye, d - Safonovka, e - Yamskaya steppe sites.

with 16 and $<100$ y duration of cultivation, the SOC concentration was less than that in the un-ploughed soils to $80-100 \mathrm{~cm}$ depth. In the arable soils with long-term duration of cultivation, there is no one-way change of SOC concentration in the central section of profiles. For the soils with 100-150 and 150-200 years of cultivation, the percentage of SOC in the middle part of a profile is similar to the un-ploughed soils (Fig. 7 I a, b, c, d). In the soils with 220-240 years of ploughing, in only one case were the SOC concentrations lower (Fig. 7 I a). In all other cases, they were greater (Fig. 7 I c) or the same (Fig. 7 I b and d) as those in the un-ploughed soils in the middle part of a profile.

\subsection{Soil inorganic carbon concentrations (\%)}

SIC concentration varied insignificantly in the un-ploughed soils: carbonates appeared in distinct quantity in the second meter of the profile of all the sites studied (Fig. 7 II). Sometimes 0.5\% SIC are found at $40-50 \mathrm{~cm}$ (Fig. 7 II d) or $80-90 \mathrm{~cm}$ (Fig. 7 II e), but at the beginning of the second meter in a profile the SIC concentrations rise to $2.0-2.5 \%$ (Fig. 7 II b, c).

In the arable Chernozems with 16 and $<100$ years of cultivation the maximum of SIC concentration is located about $40 \mathrm{~cm}$ higher in the profile than in the un-ploughed soils (Fig. 6 II a, c, e). The reaction of carbonates under water regime changes due to agricultural impact is immediate after the beginning of ploughing. In the arable soils with longer cultivation, a trend of decreasing SIC concentration to the initial level or below is observed. Sometimes, this trend is disturbed by spatial variability: in the arable soils with 220-240 years of cultivation the maximum profile distribution of the SIC concentration lies higher (Fig. 7 II a) or slightly higher (Fig. 7 II c) within a profile than that in the un-ploughed soils. As a whole, a high degree of instability of the carbonate status in the arable Chernozems is noted.

\subsection{Soil organic and inorganic carbon stocks ( $t / h a)$}

The distribution of SOC stocks in the un-ploughed and arable Chernozems of the studied sites confirms the regularity of the SOC concentration in the soils (Fig. 8 I). The $20-25 \%$ and $15-30 \%$ decrease of the SOC stocks in $0-30 \mathrm{~cm}$ and $0-50 \mathrm{~cm}$ respectively is observed for arable soils with $<100$ years of cultivation compared with the un-ploughed soils. The least decrease of the SOC stock is noted in the arable Chernozems compared with the Leached Chernozems under ash-oak forest (Fig. $8 \mathrm{I} \mathrm{b}$ ): $8 \%$ in $0-30 \mathrm{~cm}$ and $5 \%$ in $0-50 \mathrm{~cm}$. The $0-100$ and $0-200 \mathrm{~cm}$ depths were not marked by SOC loss in the arable soils in comparison with the un-ploughed
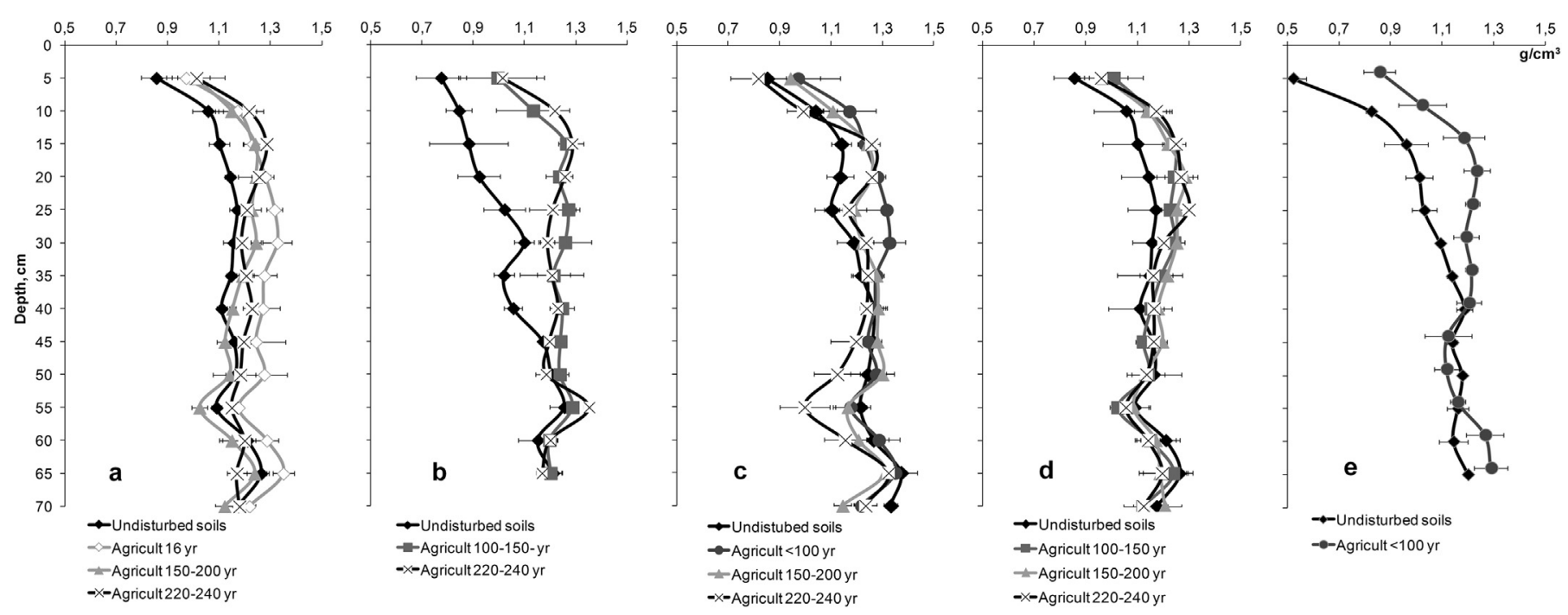

Fig. 4. Bulk density values until the $70 \mathrm{~cm}$ in soils of the key sites. Notes: a-e as Fig. 3 . 

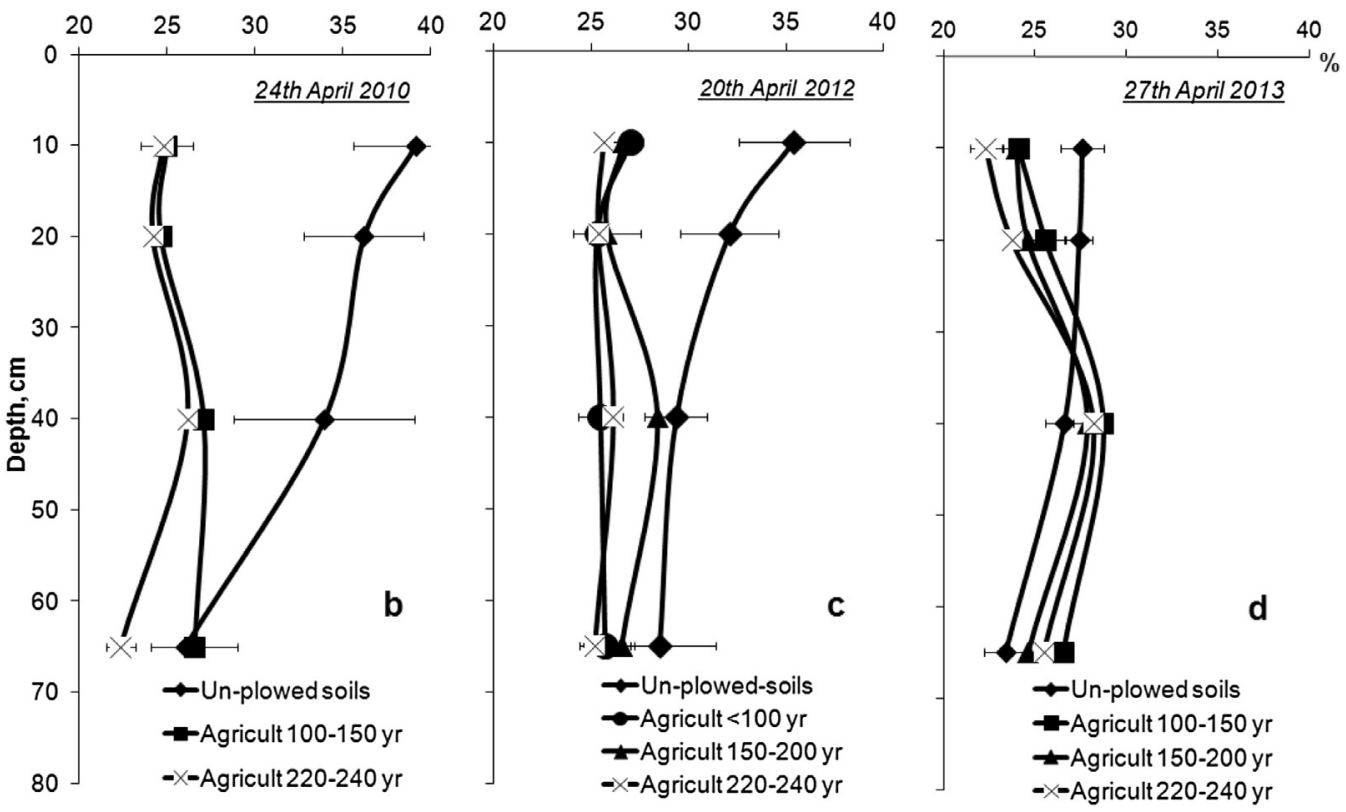

Fig. 5. Soil field moisture observed in April of different years for different key sites: b - Verkhopenye, c - Zhimolostnoye, d - Safonovka sites.

ones. The principal loss of SOC occurred in the uppermost $50 \mathrm{~cm}$ of a profile under cultivation.

None of the studied agrochronosequences showed the gradual decreasing of SOC stocks in connection with the increasing of the length of cultivation in the arable soils. The most considerable loss in all the studied layers $(0-30,0-50,50-100,0-100$ and $0-200 \mathrm{~cm}$ ) is noted in the arable soils with $<100$ years duration of cultivation. In the arable soils with 100-150 and 150-200 years of cultivation, the stabilization of the SOC stocks and their spatial variability is noted. In the arable soils with the longest duration of cultivation, 220-240 years, the weak decreasing of the SOC stocks in all the layers mentioned above is observed in two cases (Fig. $8 \mathrm{I}$ $\mathrm{a}-\mathrm{b})$, and in the other two cases only spatial variability is registered (Fig. 8 I c, d). Further decreasing of the SIC stocks in the process of the agrogenic evolution of the arable Chernozems with more than 100 years duration of cultivation could not be ascertained.

SIC stocks are stable higher in the arable soils with 16 and $<100$ years of cultivation that those in the un-ploughed soils (Fig. 8 II).
The greatest contribution to this increase is made due to the increase of SIC stocks in the $50-100 \mathrm{~cm}$ layer. Sometimes this increase is noted at $0-50 \mathrm{~cm}$ (Yamskaya steppe site, Table $1 \mathrm{e}$ ). In the arable Chernozems with longer lengths of cultivation, 100-150 and 150-200 years, the gradual decreasing of the SIC stocks is observed. The differences in pairs of soil pits situated on a field of the same length of cultivation are very high and there is a considerable growth of standard deviation in the arable soils with $>100$ years of cultivation. The latter is especially true for the Zhimolostnoye and Safonovka sites (Fig. 8 II c and d). As for the arable soils with 220-240 years of cultivation, it can be supposed with caution that the SIC stocks are reverting or receding compared with the unploughed soils.

\section{Discussion}

According to the data obtained, considerable changes in soil properties due to ploughing may be ascertained. Firstly, the

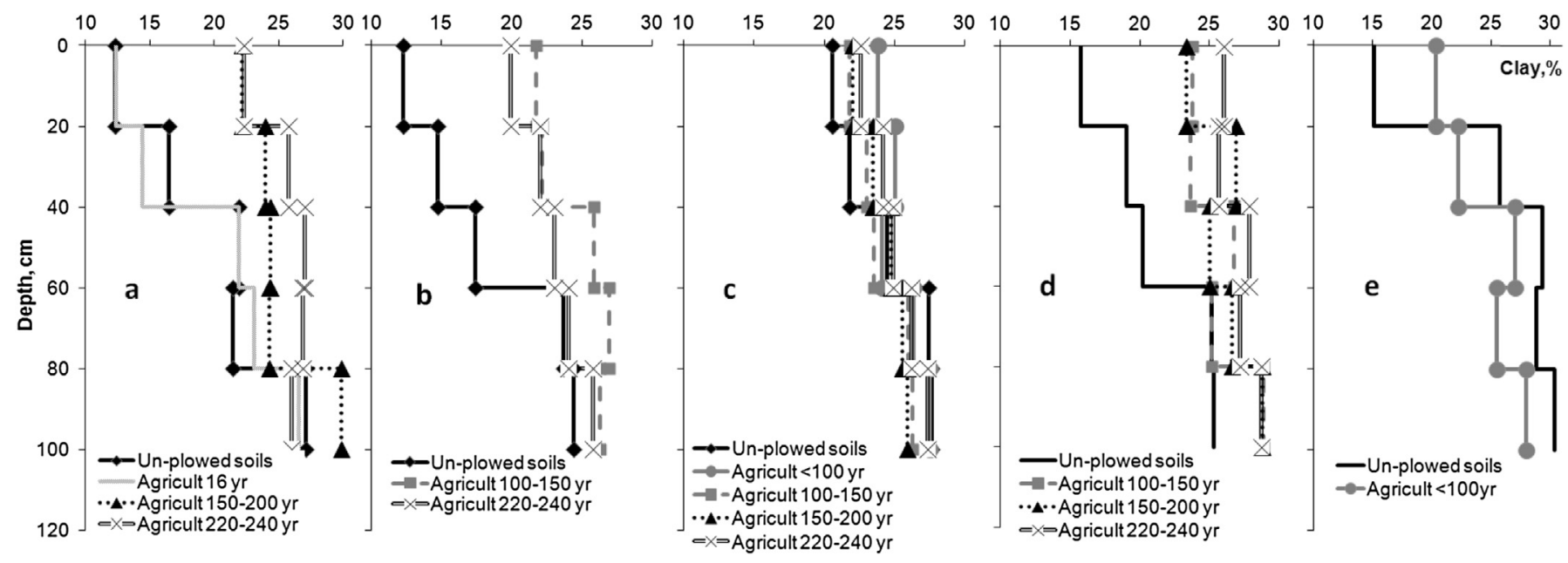

Fig. 6. Clay fraction distribution in profiles of soils of the key sites. a-e as Fig. 3. 

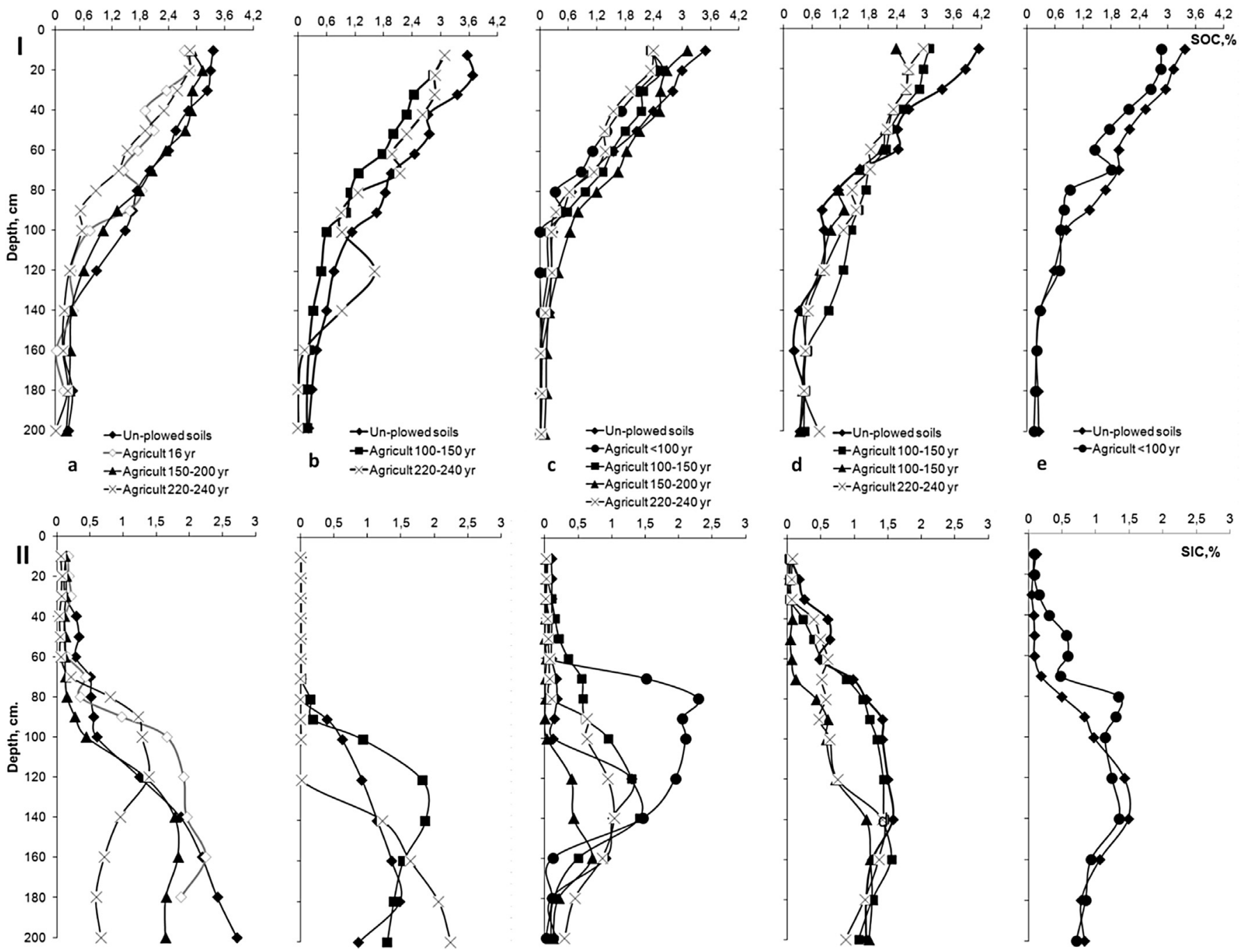

Fig. 7. Profile distribution of SOC (I) and SIC (II) in soils of the key sites. a-e as Fig. 3.

morphology of un-ploughed and arable soils differs. In the arable soils, a "new" annually agitated Ap horizon with practically smooth lower boundary appears. The burrowing animals' activity is very high and differs markedly in a pair of similarly-aged pits of the arable soils. The difference in morphology in the pairs of unploughed pits of each site is mostly determined by the variability in parent rocks. This difference in the pairs of arable pits is heightened by the activity of burrowing animals. The enhancement of the burrowing animals' activity in layers under ploughing horizon to $100-120 \mathrm{~cm}$ has been already noted in the long-term arable Gray Forest soils of the region (Chendev et al., 2011; Khokhlova et al., 2014). This activity has an influence on the humus profile thickness and position of carbonates in the arable soils. It is not clear yet why the burrowers dig the arable soils unequally, and this phenomenon requires future investigation.

Our data on the bulk density and soil moisture changing in the arable soils agree with those obtained by I.I. Lebedeva. The most significant change in the values of bulk density and increasing of compaction of the upper part of the arable soils took place in the initial period ( $<100$ years) after the beginning of ploughing.

The clay deposition of the uppermost layers which was noted in the arable soils leads to the compaction of a soil mass and to the increase of specific surface area inside this layer. As a whole, the process of clay fraction migration is enforced due to mechanical crushing of coarse particle-size fractions under machine ploughing and disintegration of soil structural aggregates (Agroecological status ..., 1996; Butova et al., 1996). The clay fraction enrichment may be a reason of evident slowdown of the humus loss in the arable soils over time.

From our point of view, the redistribution of SOC in the arable Chernozems of different duration of cultivation is firstly connected with the humus backfill in the cracks and activity of burrowing animals, and secondly with the clay enrichment of the middle part of arable soils. The clay-enriched soils are comparatively SOC rich (Burke et al., 1989). Relocation of clay fraction from the uppermost ploughing horizon to $80-100 \mathrm{~cm}$ depth causes not only the SOC enrichment of the central section of a profile for arable soils but a high degree of SOC resistance to bio-mineralization. According to previous research (Chukov, 1998; Schnitzer et al., 2006; Ovchinnikova, 2013), the quantity of labile fractions of humus decreased and the relative growth of quantity of stabile fractions is observed in arable Chernozems. These are fractions connected with sesquioxides and clay. Due to the latter, a clear reduction in the SOC concentration in the central section of a profile in the arable soils with 200 or more years of cultivation is not detected. In addition, the similar redistribution of the SOC concentrations in the middle part of a profile for the long-term cultivated Agro-Chernozems (former Gray Forest soils) due to activity of burrowing animals 

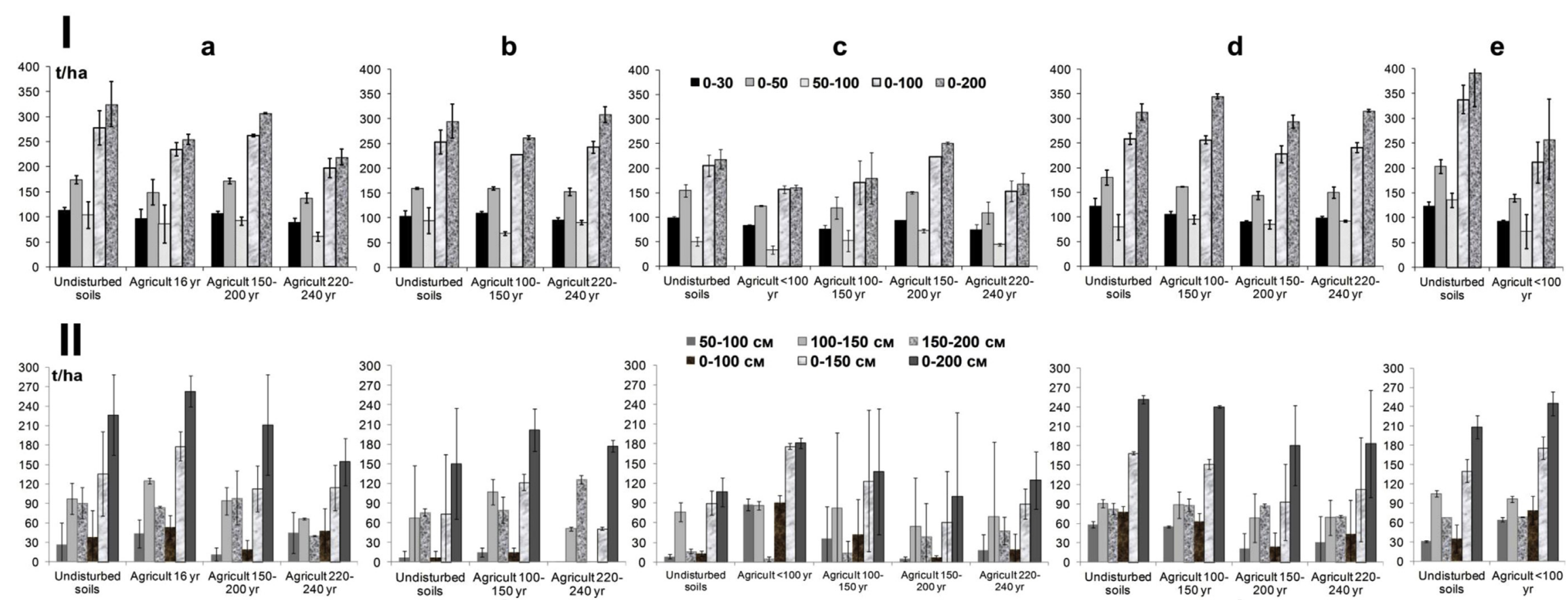

$=50-100 \mathrm{~cm} \quad \square 100-150 \mathrm{~cm} \quad \mathbb{1 5 0 - 2 0 0} \mathrm{cm}$

$=0-100 \mathrm{~cm} \quad \square 0-150 \mathrm{~cm} \quad \square 0-200 \mathrm{~cm}$

Fig. 8. SOC (I) and SIC (I) in different layers within the 2-m thick soil profiles in soils of the key sites. a-e as Fig. 3 . 
was previously observed in the region (Khokhlova et al., 2014). Therefore, this activity cannot be ignored especially as we have already noted increasing morphological signs of it in the studied arable Chernozems with $>100$ years duration of cultivation.

It is possible to detect some stages of the SOC stocks' changes under agricultural impact. On the first stage in the arable soils with $<100$ years of cultivation, a clear loss of SOC stocks occurred due to abrupt decrease of input of plant residues in agriculture compared with input in the un-ploughed soils. The most significant changes in soil properties, especially loss of original SOC, occurred in the earliest stages after the beginning of ploughing, after 3, 40, 50 years, as noted in the steppe soils within other world regions (Campbell and Souster, 1982; Tiessen et al., 1982; Mann, 1985; Bowman et al., 1990; Rasmussen and Parton, 1994; Klimowicz and Uziak, 2001).

In the arable soils with the $>100$ years of cultivation, stabilization of the SOC stocks at the "new" reduced level (sometimes close to un-ploughed soils - Fig. 7 I a, c, d) is observed due to two processes. These are the redistribution of organic carbon from the upper to the middle part of a profile along cracks appeared as a result of constant dryness of a plough-layer, and fixation of stable humus fractions together with clay fractions. In addition, it seems that the activity of burrowing animals plays an important role in stabilization of humus status and stopping of the further SOC loss in the arable Chernozems. After 200 years of cultivation, there are weak signs of resumption of the SOC loss under the agricultural impact, but the further fate of SOC will be clear in the course of future investigation.

According to our previous research of redistribution of carbonates in soils under agrochemical affects (Kuznetsova et al., 2010; Khokhlova et al., 2014), carbonates are uplifted in the arable Chernozems from the lower horizons of a soil profile or from the carbonate-rich parent rocks. As a whole, the pattern of carbonate status change in the arable soils with $>100$ years of cultivation is not quite clear. We can only assert that the spatial variability of measured properties of carbonate status, namely, the depth of effervescence with HCL, the percentage of carbonates in the profile and their stocks, are dramatically enhanced in the studied arable soils.

\section{Conclusions}

For the Central Russian forest-steppe, anthropogenic (agrogenic, agricultural) evolution of Chernozems examined in the agrochronosequences can be divided into stages. The most appreciable changes occurred with the arable Chernozems in the first period after the beginning of cultivation. In the arable soils with 16 and $<100$ years duration of cultivation, the following changes are observed: $5-7$ to $9 \mathrm{~cm}$ decrease of the humus profile, compacting of the plough-layer and its initial enrichment by clay fraction, $15-30 \%$ decrease of the SOC content and stocks in the $0-30$ and $0-50 \mathrm{~cm}$, about $40 \mathrm{~cm}$ uplifting of carbonate accumulation towards the soil surface, and increasing of SIC content and stocks at $0-100$ and $0-200 \mathrm{~cm}$. These changes occurred due to abrupt decreasing of the plant residues in agriculture, influence of machinery treatment resulting in the destruction of the plough-layer structure, compaction of this layer and physical crushing of coarse particlesize fraction, and changes of water regime in the arable soils.

In the arable soils with longer duration of cultivation, 100-150 and 150-200 years, we did not see the further compaction of a soil mass, continuing loss of SOC, and uplifting of carbonates. The backfilling of the SOC along the cracks in the middle part of a profile, high activity of the burrowing animals, continuing redistribution of clay fraction in the deeper horizons resulted in stabilization of SOC stocks in a profile of the arable soils on the "new" reduced or sometimes close to the initial level and replacement carbonates to the initial (before cultivation) or lower level of location, concentrations and stocks in a profile.

For the arable Chernozems with 220-240 years duration of cultivation, the definite direction of their evolution under further agriculture influence was unclear. The high instability concerning studied indicators of the humus and carbonate status is only emphasized. The evolution for the long-term cultivated Chernozems may be clear in the course of future investigation.

Rapid changes of Chernozem properties after the beginning of ploughing and their considerable slowing subsequently are evident. The activity of burrowing animals introduces an ambiguity in the trends of development of the long-ploughed Chernozems in the agrochronosequences we studied. This factor was previously underestimated.

\section{Acknowledgements}

This work has been supported by RFBR, grants N 12-05-97512-ra, 12-04-00201-a, 14-44-03620-r-centre-a.

\section{References}

Aderikhin, P.G., 1964. Change of Chernozem-type soils of the Central Chernozemic oblast at their use in agriculture. In: Rode, A.A. (Ed.), Chernozems of the Centra Chernozemic Oblast and Their Fertility. Nauka Press, Moscow, pp. 64-89 (in Russian).

Afanasyeva, E.A., 1964. Formation and regime of thick Chernozems. Chernozems of the Central Chernozemic oblast and their fertility. In: Rode, A.A. (Ed.), Chernozems of the Central Chernozemic Oblast and Their Fertility. Nauka Press, Moscow, pp. 5-64 (in Russian).

Afanasyeva, E.A., 1966. Chernozems of the Middle Russian Upland. Nauka press, Moscow, p. 223 (un Russian).

Shcherbakov, A.P. Vasenev, I.I. (Eds.), 1996. Agroecological State of Chernozems in the Central Chernozemic Region of Russia. All-Russian Research Institute of agriculture and protection of soils from erosion Press, Kursk, p. 326 (in Russian).

Akhtyrtsev, B.P., 1991. Ecological problems of use, anthropogenic evolution and current state of the Central Russian Chernozem. Voronezhsky kraeved 1, 104-117 (in Russian).

Akhtyrtsev, B.P., Akhtyrtsev, A.B., 2002. Changes in the humus state of forest-steppe and steppe Chernozems resulting from their long-term ploughing and sealing under burial mounds. Eurasian Soil Science 35 (2), 123-131.

Akhtyrtsev, B.P., Shchetinina, A.S., 1969. Changes of the Grey Forest Soils in the Process of Their Agricultural Use. Mordovsky University Press, Saransk, p. 164 (in Russian).

Aleksandrovskiy, A.L., 1988. Use of the methods of pedology for the historical geography. In: Historicka Geografie. Published on the Occasion of the 26th International Geographical Congress, Sydney, 1988, 27. Ustav ceskoslovenskych a svetovych dejin CSAV, Praha, pp. 123-149.

Al-Kaisi, M.M., Yin, X., Licht, M.A., 2005. Soil carbon and nitrogen changes as influenced by tillage and cropping systems in some Iowa soils. Agriculture, Ecosystems \& Environment 105 (4), 635-647.

Arinushkina, E.V., 1970. Manual on the Chemical Analysis of Soils. Moscow State University Press, Moscow, Russia, p. 487 (in Russian).

Blanco-Canqui, H., Schlegel, A.J., Heer, W.F., 2011. Soil-profile distribution of carbon and associated properties in no-till along a precipitation gradient in the central Great Plains. Agriculture, Ecosystems \& Environment 144 (1), 107-116.

Bowman, R.A., Reeder, J.D., Lober, R.W., 1990. Changes in soil properties in a central Plains rangeland soil after 3, 20, and 60 years of cultivation. Soil Science 150 (6), $851-857$.

Brekhova, L.I., Shcheglov, D.I., 2001. Features of changes in carbonate profile of typical Chernozem under agricultural use. In: All-Russian Conference "Problems of Soil Evolution": Proc. of Reports. POLTEKS Press, Moscow, pp. 155-156 (in Russian).

Brook, M.S., 1979. Influence of long-term agricultural treatment on the changes of Chernozems. Pochvovedenie 8, 124-127 (in Russian).

Burke, I.C., Yonker, C.M., Parton, W.J., Cole, C.V., Flach, K., Schimel, D.S., 1989. Texture, climate, and cultivation effects on soil organic matter content in US grassland soils. Soil Science Society of America Journal 53 (3), 800-805.

Butova, L.S., Parfenova, O.A., Shcherbakov, A.M., 1996. Processes of clay distribution in Chernozems of different croplands. In: Proceedings of the Int. Conf. of Students and Post-graduate Students on the Fundamental Science "Lomonosov96", Section "Soil Science”. Lomonosov Moscow State University Press, Moscow, pp. 10-11 (in Russian).

Campbell, C.A., Souster, W., 1982. Loss of organic matter and potentially mineralizinle nitrogen from Saskatchewan soils due to cropping. Canadian Journal of Soil Science 62, 651-656.

Chendev, YuG., 2008. Evolution of Forest-steppe Soils within the Russian Upland in the Holocene. GEOS Press, Moscow, Russia, p. 212 (in Russian). 
Chendev, YuG., Aleksandrovskiy, A.L., Khokhlova, O.S., Smirnova, L.V., Novykh, L.L., Dolgykh, A.V., 2011. Anthropogenic evolution of Dark Gray forest-steppe soils in the southern part of the Central Russian Upland. Eurasian Soil Science 44 (1), $1-12$.

Chukov, S.N., 1998. Study of humic acids in anthropogenically disturbed soils using C-NMR spectroscopy. Eurasian Soil Science 31 (9), 979-986.

Dobrovolsky, G.V. (Ed.), 2004. Classification and Diagnostics of Soils in Russia. Oykumena Press, Smolensk, p. 342 (in Russian).

Denisov, P.S., 1935. Soils of Voronezh and Kursk Regions and Their Relation to Agrotechnology. Voronezhskoje oblastnoe knizhnoje izdatelstvo, Voronezh, p. 58 (in Russian).

Francaviglia, R., Benedetti, A., Doro, L., Madrau, S., Ledda, L., 2014. Influence of land use on soil quality and stratification ratios under agro-silvo- pastoral Mediterranean management systems. Agriculture, Ecosystems \& Environment 183, 86-92.

Gedymin, A.V., Kharitonychev, A.T., 1964. Use of old cartographic materials for a landscape study. In: Gerasimov, I.P. (Ed.), Modern Problems of Geography. Nauka Press, Moscow, pp. 298-302 (in Russian).

Gedymin, A.V., Pobedintseva, I.G., 1964. Experience of investigation of the longterm ploughing on the properties of ordinary Chernozems. Pochvovedenie 5 35-46 (in Russian).

Gerasomov, I.P., 1983. Concept "soil-natural body" and its derivatives ("soilregime", "soil-reproduction", "soil-memory"). Pochvovedenie 4, 5-12 (in Russian).

Ivanov, A.L., Lebedeva, I.I., Grebennikov, A.M., 2013. Factors for anthropogenic transformation of Chernozems. Bulletin of Dokuchaev Soil Science Institute 71, 26-46 (in Russian).

Ivanov, I.V., Tabanakova, E.D., 2003. Change of thickness of humus horizon and evolution of Chernozems in Eastern Europe during the Holocene (mechanisms, reasons, regularities). Pochvovedenie 9, 1029-1042 (in Russian).

Karavaeva, N.A., Zharikov, S.N., Nephedova, T.G., 1989. Anthropogenic transformation of soils. In: Mandych, F.A. (Ed.), Environment of the European Part of the USSR. Experience of the Regional Analysis. Academy of Sciences of the USSR Press, Moscow, pp. 80-153 (in Russian).

Klimowicz, Z., Uziak, S., 2001. The influence of long-term cultivation on soil properties and patterns in an undulating terrain in Poland. Catena 43 (3), 177-189.

Kokovina, T.P., Lebedeva, I.I., 1986. Current hydrothermal regimes and genetic and geographic features of Chernozems in European part of the USSR. In: Kovda, V.A., Glazovskaya, M.A. (Eds.), Advances of Soil Science. Soviet Soil Scientists to the 13th Congress of Soil Science in Hamburg. Nauka Press, Moscow, pp. 148-153 (in Russian).

Kokovina, T.P., Lebedeva, I.I., 1990. Current state of arable Chernozems. Fertility of Chernozems due to the intensification of their use. In: Proceeding of Dokuchaev Soil Science Institute. Academy of Agricultural Sciences Press, Moscow, pp. 27-35 (in Russian).

Kozlowskiy, F.I., 2003. Evolution of ploughed soils as a subject for genetic and geographic pedology. In: Theory and Methods of Study of Soil Cover (Collection of Works). GEOS Press, Moscow, pp. 451-463 (in Russian).

Kuznetsova, A.M., Khokhlova, O.S., Chendev, YuG., Aleksandrovskii, A.L., 2010. Evolution of the carbonate state of agriculturally transformed dark grey forest soils in the central forest-steppe. Eurasian Soil Science 43 (13), 1527-1534.

Khokhlova, O.S., Chendev, YuG., Myakshina, T.N., 2014. Change in pedogenic carbon stocks under different types and duration of agricultural management practices in the central Russian forest steppe. In: Oelbermann, M. (Ed.), Sustainable Agroecosystems in Climate Change Mitigation. Wageningen Academic Publishers, pp. 33-52.
Lazarev, A.A., 1936. Influence of Agrochemical Culture on Properties of Chernozems in the Forest-steppe Area. USSR Academy of Sciences Press, Moscow, p. 71 (in Russian).

Lebedeva, I.I., 2002. Hydrological profiles of migrational carbonate (typical) Chernozems and Agro-Chernozems. Pochvovedenije 10, 1214-1223 (in Russian).

Lebedeva, I.I., Koroleva, I.E., Grebennikov, A.M., 2013. Conception of evolution of Chernozems in agro-ecosystems conditions. Bulletin of Dokuchaev Soil Science Institute 71, 16-26 (in Russian).

Mann, L.K., 1985. A regional comparison of carbon in cultivated and uncultivated Alfisols and Mollisols in the central United States. Geoderma 36, 241-253.

Grin, A.M., Mukhina, L.I. (Eds.), 1989. Natural and Anthropogenic Geosystems of the Central Forest-steppe of the Russian Plain. Nauka Press, Moscow, p. 276 (in Russian).

Oganovskiy, N., 1911. Regularity of Agrarian Evolution. In: Essays on the History of Land Relationships in Russia. Sotrudnichestvo press, Saratov part II, 632 pp. (in Russian).

Orlov, D.S., Biryukova, O.N., Sukhanova, N.I., 1996. Soil Organic Matter of Russia. Nauka Press, Moscow, 256 pp. (in Russian).

Ovchinnikova, M.F., 2013. Features of natural stability and agrogenic transformation of soil humus. Eurasian Soil Science 46 (12), 1150-1163.

Pobedintseva, I.G., 1989. Change in microstructure of Chernozem in forest-steppe of the Russian plain under influence of economic use. Bulletin of Dokuchaev Soil Science Institute 51, 5-6 (in Russian).

Ponomareva, V.V., 1974. On genesis of humus profile in Chernozem. Pochvovedenie 7, 6-16 (in Russian).

Rasmussen, P.E., Parton, W.J., 1994. Long-term effects of residue management in wheat-fallow. I: inputs, yield, and soil organic matter. Soil Science Society of America Journal 58 (2), 523-530.

Schnitzer, M., McArthur, D.F.E., Schulten, H.-R., Kozak, L.M., Huang, P.M., 2006. Longterm cultivation effects on the quantity and quality of organic matter in selected Canadian prairie soils. Geoderma 130 (1-2), 141-156.

Shcheglov, D.I., 1999. Chernozems of the Central Russian Plane and Their Evolution under Natural and Anthropogenic Factors. Nauka Press, Moscow, p. 214 (in Russian).

Sidorov, M.I., Khabarov, N.I., Nebolsin, I.M., 1983. Efficiency and Improving of Farming Systems in the Central Chernozemic Region. Central - Chernozemic knizhnoje isdatelstvo, Voronezh, p. 94 (in Russian).

Sinkevich, Z.A., 1989. Modern Processes in the Chernozems of Moldova. Shtiintsa Press, Chisinau, p. 214 (in Russian).

Tiessen, H., Stewart, J.W.B., Betany, J.R., 1982. Cultivation effect on the amounts and concentration of carbon, nitrogen and phosphorus in grassland soils. Agronomy Journal 74, 831-835.

Ushacheva, T.I., Zvyagintsev, S.S., 2000. Change of morphology in the Dark Kastanozems with residual solonetzic properties as a result of agrochemical use. In: Steppe of the Northern Eurasia: Strategy of Protection of Biodiversity and Steppe Natural Management in the 21th Century. Proceedings of the International Symposium. Institute of steppe Russian Academy of Sciences Press, Orenburg, pp. 385-386 (in Russian).

Uvarov, G.I., Solovichenko, V.D., 2010. Degradation and Conservation of Soils in Belgorod Oblast. Otchiy krai press, Belgorod, p. 180 (in Russian).

Yu, Y., Huang, Y., Zhang, W., 2013. Projected changes in soil organic carbon stocks of China's croplands under different agricultural managements, 2011-2050. Agriculture, Ecosystems \& Environment 178, 109-120.

Zonn, S.V., Travleev, A.P., 1989. Geographic and Genetic Aspects of Soil Formation, Evolution and Protection. Naukova dumka Press, Kiev, p. 214 (in Russian). 